\title{
Article \\ Effect of Radio-Frequency Treatment on the Changes of Dissolved Organic Matter in Rainwater
}

\author{
Ariadi Hazmi ${ }^{1}$, Maulana Yusup Rosadi ${ }^{2}$, Reni Desmiarti ${ }^{3, *}$ and Fusheng Li ${ }^{4}$ \\ 1 Department of Electrical Engineering, Andalas University, Padang 25166, Indonesia; ariadi@eng.unand.ac.id \\ 2 Graduate School of Engineering, Gifu University, Gifu 501-1193, Japan; y3921021@edu.gifu-u.ac.jp \\ 3 Department of Chemical Engineering, Universitas Bung Hatta, Padang 25173, Indonesia \\ 4 River Basin Research Center, Gifu University, Gifu 501-1193, Japan; lifs@gifu-u.ac.jp \\ * Correspondence: renitk@bunghatta.ac.id
}

check for updates

Citation: Hazmi, A.; Rosadi, M.Y.; Desmiarti, R.; Li, F. Effect of Radio-Frequency Treatment on the Changes of Dissolved Organic Matter in Rainwater. Water 2022, 14, 111. https://doi.org/10.3390/w14010111

Academic Editors: Vincenzo Naddeo and Chi-Wang Li

Received: 1 December 2021

Accepted: 31 December 2021

Published: 5 January 2022

Publisher's Note: MDPI stays neutral with regard to jurisdictional claims in published maps and institutional affiliations.

Copyright: (C) 2022 by the authors. Licensee MDPI, Basel, Switzerland. This article is an open access article distributed under the terms and conditions of the Creative Commons Attribution (CC BY) license (https:// creativecommons.org/licenses/by/ $4.0 /)$.

\begin{abstract}
Rainwater is a potential source of drinking water, but has various components of dissolved organic matter (DOM). DOM is a reservoir of potential hazards in drinking water. Therefore, a new method is required to purify rainwater as a drinking water source in terms of DOM aspects. A radiofrequency (RF) treatment system is introduced here to purify source water with a small possibility of contamination. RF is generated by applying a frequency of $1.5 \mathrm{MHz}$ through a glass reactor with a diameter of $2 \mathrm{~mm}$ which is wrapped by a $2 \mathrm{~mm}$ copper wire. The results demonstrate that $\mathrm{UV}_{260}$ value and dissolved organic carbon (DOC) are reduced during RF treatment. DOC was reduced by a lower amount compared to $\mathrm{UV}_{260}$, suggesting the partial transformation of bio-refractory DOM. A fluorescence excitation-emission matrix showed that humic-like substances in rainwater were reduced faster than protein-like ones, indicating that humic-like substances are susceptible to reduction by $\mathrm{RF}$ treatment. The results offer information on the use of RF treatment in a rainwater purification process for the production of drinking water.
\end{abstract}

Keywords: dissolved organic matter; radio-frequency treatment; rainwater; humic-like substances

\section{Introduction}

Due to the economics of water scarcity, rainwater has become popular as an alternative drinking water source in areas with a high rainfall rate, deficient centralized systems, or where pressure on water resources surpasses the recharge capacity [1]. Rainwater can be transformed into drinking water when the supply capacity is drastically reduced due to climate change $[2,3]$. The field of water resource management in large urban areas has emerged to support the development and sustainability of the water supply, as well as the treatment of discharges of rainwater. Rainwater harvesting is one way to effectively reduce excess surface runoff and flooding risk, while producing an alternative drinking water source, and an emergency water supply, thus reducing water bills and operational costs [4].

With the recent concerns for sustainability as well as development of safe drinking water, rainwater has gained increasing interest as a safe water supply option [5]. Urban rainwater tank systems have undergone a surge to promote water conservation in both developed and developing countries [6]. In African and Asian developing countries, including Indonesia, the utilization of rainwater as a water supply is being brought to urban areas, with the support of the government. In Australia, rainwater is used for non-drinking purposes, such as for gardening or toilet flushing; only $2 \%$ of the Australian population uses rainwater as drinking water [6]. Countries in Europe, such as Germany and Sweden, have developed rainwater harvesting systems for urban use, toilet flushing, fire protection and flood control $[7,8]$. However, the practice of transforming rainwater to drinking water is still rare, and only a few projects have been reported to date [9]. In Indonesia and Vietnam, rainwater has been traditionally utilized for drinking water through the boiling method $[5,10]$. Nevertheless, there are no standard regulations on 
the use of rainwater as a source of drinking water. Substances such as dissolved organic matter (DOM) and microorganisms in rainwater may not be effectively removed through the simple disinfection method of boiling [10]. Thus, the health issues inflicted from the unsafe utilization of rainwater have been a major concern in the use and maintenance of rainwater for drinking systems.

Studies have demonstrated that rainwater contains DOM in various concentrations and of varied composition [11,12]. DOM is a part of natural organic matter (NOM) along with particulate organic matter (POM) that consists mainly of microorganisms [13]. However, the proportion of DOM is higher than POM (>65\% of total NOM) [14], and thus the study on DOM in rainwater and other water sources is gaining more interest. DOM in rainwater originates from various sources, such as gaseous dissolution, soil dust re-suspension, marine organic matter evaporation, fossil fuel combustion, and biomass burning [15-17]. The presence of DOM in rainwater plays a crucial role in the changes in the atmospheric environment, cloud albedo, inputs to the land ecosystem, biogeochemical cycles, and global climate change $[4,18,19]$. Rainwater as an alternative source of drinking water requires a purification process to achieve water quality standards for drinking purposes [20]. Conventional treatments, such as coagulation, flocculation, sedimentation, and sand filtration have been widely used to remove large types of DOM from the water source. Adding chlorine to rainwater is an obligatory operation for reducing DOM, but simultaneously increases the chemical risks [21]. However, conventional treatments for rainwater are insufficient to completely remove pollutants with a low molecular size of DOM.

To achieve the reduction of DOM in rainwater through a chemical process, numerous purification processes have been used in terms of the oxidation process that promotes a faster reduction of DOM with low molecular size in water. Radio-frequency (RF) is an electromagnetic field system in the frequency range of $20 \mathrm{kHz}$ to $300 \mathrm{GHz}$ [22-24]. RF technology has been used for diverse purposes in many different areas. RF treatment is among the advanced treatments used to purify the water source with a lower possibility of contamination. RF generates electrons, free radicals, ions, and neutral ionized gas that can enable plasma substances to reach thermal equilibrium and decompose organic compounds in water $[25,26]$. RF currents in conductors can radiate into space as radio waves and induce heat to provide physical and chemical effects in solution that are capable of degrading high molecular weight organic pollutants $[27,28]$. RF can generate oxidant species such as hydroxyl radicals $(\bullet \mathrm{OH})$, hydrogen peroxide $\left(\mathrm{H}_{2} \mathrm{O}_{2}\right)$, and ozone $\left(\mathrm{O}_{3}\right)$, and these oxidizing species have a high potential to decompose organic compounds in water [29-31].

Numerous studies have focused on a single oxidant species generated by an advanced oxidation process on DOM transformation. Voronstov [32] and Ya et al. [33] demonstrated that $\bullet \mathrm{OH}$ could oxidize most organic matter, and even completely mineralize it, ultimately generating carbon dioxide and water. DOM was significantly degraded by $\mathrm{O}_{3}$ with a specific ozone dose of $0.5-1.5 \mathrm{mgO}_{3} / \mathrm{mgC}$ and reached sufficient degradation in $30 \mathrm{~min}$ [34]. This oxidation treatment can promote a high removal efficiency for removing organic compounds, yet the demerit of this oxidation treatment is that corrosion may occur on the electrode surface due to direct contact with water in the reactor. Therefore, the utilization of RF can promote DOM reduction efficiency without causing corrosion because there is no direct contact with the water. In the current study, the purpose was to validate the potential utilization of RF treatment to reduce the DOM composition and concentration in rainwater. The validation study was assessed by the reduction of DOM during treatment and to help further the development of an optimization strategy for utilization rainwater as a drinking water source.

\section{Materials and Methods}

\subsection{Rainwater}

Rainwater was collected from domestic residence roof catchments located in Padang, West Sumatra, Indonesia, in daily rainfall events for 8 days (25 June-8 July 2019). Rainwater was collected using $500 \mathrm{~mL}$ pre-chlorinated glass bottles and 8 samples were collected 
during the investigation. The nearest meteorological station to the sampling location is Maritim Teluk Bayur $(8 \mathrm{~km})$. The available data of average rainfall for the site was $214 \mathrm{~mm}$, originating over a mountainous area [35]. A sterile glass bottle was used to collect rainwater manually.

\subsection{RF Treatment}

Figure 1 depicts the experimental set-up used in this study. The system consists of a MI007 passive oscilloscope probe, a current probe (P6021A Tektronix), an RF generator and a reactor. The RF reactor has a length of $30 \mathrm{~cm}$ and a diameter of $7.62 \mathrm{~cm}$, coupled by a copper wire $(\varnothing 2 \mathrm{~mm})$, with a frequency of $1.5 \mathrm{MHz}$ and an electric current of $3 \mathrm{~A}$. The collected rainwater was transferred to the water tank, pumped with a flow rate of $200 \mathrm{~mL} / \mathrm{min}$ through a cartridge filter and allowed to flow through the reactor. The treated rainwater was analyzed for dissolved organic carbon (DOC), ultra-violet absorbance at $260 \mathrm{~nm}\left(\mathrm{UV}_{260}\right)$, fluorescence excitation-emission matrix (EEM), and molecular weight (MW) distribution.

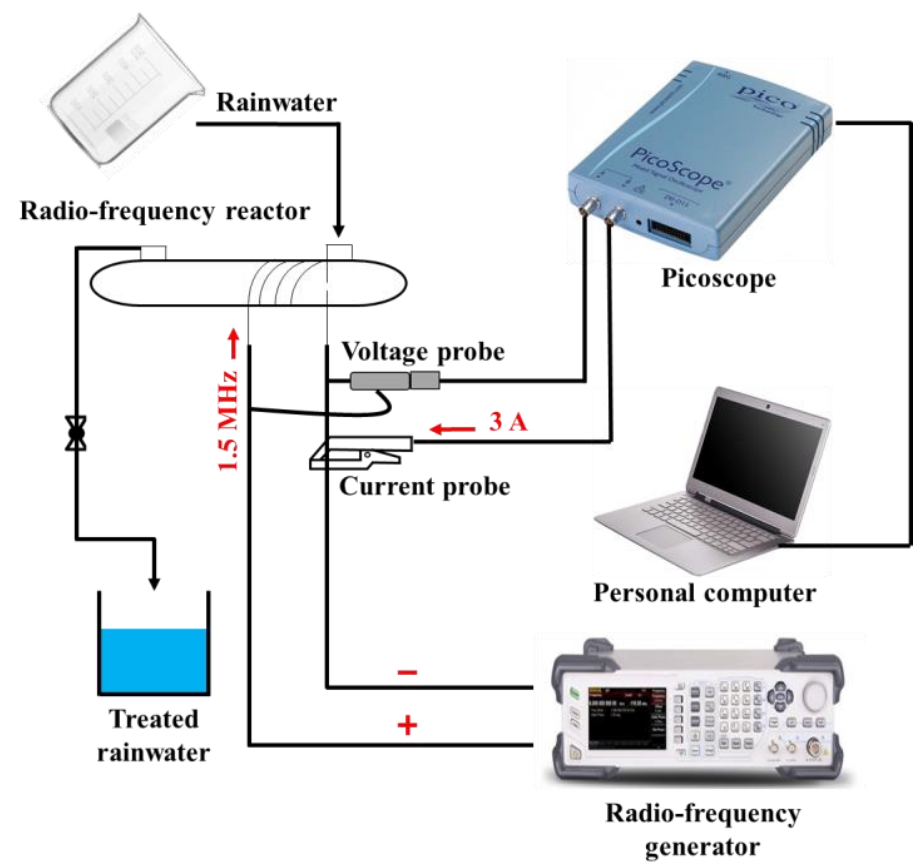

Figure 1. Experimental set-up of an RF treatment.

\subsection{DOM Analysis}

The DOC was quantified with a TOC analyser (TOC-V $\mathrm{V}_{\text {wet }}$, Shimadzu, Japan). Pure water was measured prior to the standard solution and samples to confirm the sensitivity of the measurement. Five different concentrations $(0.0 ; 0.5 ; 1.0 ; 2.0$ and $5.0 \mathrm{mg} / \mathrm{L})$ of standard solution containing $1,000 \mathrm{mg}-\mathrm{C} / \mathrm{L}$ of potassium hydrogen phthalate was used for DOC measurement. The linear regression obtained from the measurement of the standard solution was 0.9998 . The $\mathrm{UV}_{260}$ was measured by a UV-vis spectrophotometer (UV-2600, Shimadzu, Tokyo, Japan). A 1-cm cuvette was used to measure pure water prior to the samples to confirm the sensitivity of the analysis. The scanning wavelength of 220-500 $\mathrm{nm}$ was used with medium scanning speed $(400 \mathrm{~nm} / \mathrm{min})$ and the data pitch of $1 \mathrm{~nm} . \mathrm{pH}$, electric conductivity (EC), and total dissolved solids (TDS) were measured with the procedures described in the APHA standard methods. Dissolved ions: nitrite $\left(\mathrm{NO}_{2^{-}}\right)$, nitrate $\left(\mathrm{NO}_{3^{-}}\right)$, ammonium $\left(\mathrm{NH}_{4}^{+}\right)$, sulfate $\left(\mathrm{SO}_{4^{2-}}\right)$, calcium $\left(\mathrm{Ca}^{2+}\right)$, magnesium $\left(\mathrm{Mg}^{2+}\right)$ and potassium $\left(\mathrm{K}^{+}\right)$were measured using an ion chromatography system (LC-20AD SP, Shimadzu, Japan). 
The fluorescence EEM spectra of the rainwater were measured by a spectrofluorometer (RF-5300, Shimadzu, Japan). A 1-cm cuvette and high-sensitivity cell holder were used for the measurement. The excitation and emission scans showed a wavelength in the range of $200 \mathrm{~nm}$ and $550 \mathrm{~nm}$, at $5 \mathrm{~nm}$ increments. The obtained fluorescence intensity of rainwater was normalized using the quinone sulphate unit (QSU) by dividing the fluorescence intensity values of rainwater by that of $10 \mu \mathrm{g} / \mathrm{L}$ quinone sulphate (in a $0.05 \mathrm{M}$ sulfuric acid solution), at the designated excitation wavelength (Ex) of $350 \mathrm{~nm}$ and the emission wavelength (Em) of $450 \mathrm{~nm}$. High pressure size exclusion chromatography (HPSEC) was used to evaluate the MW characteristics of the DOM at a wavelength of $260 \mathrm{~nm}$. HPSEC consisted of a silica chromatographic column (GL-W250-X, $10.7 \times 450 \mathrm{~nm}$, Hitachi, Tokyo, Japan) and a UV detector (LC-10AV, Shimadzu). Pure water containing $0.02 \mathrm{M}$ of $\mathrm{Na}_{2} \mathrm{HPO}_{4}$ and $0.02 \mathrm{M}$ of $\mathrm{KH}_{2} \mathrm{PO}_{4}$ was used as the eluent, and was introduced to the column at a constant flow rate of $0.5 \mathrm{~mL} / \mathrm{min}$.

\section{Results and Discussion}

\subsection{Characteristics of Rainwater}

A RF treatment for the degradation of DOM was investigated to improve rainwater quality as an alternative source for drinking water. Several prominent water quality parameters have been analyzed, including $\mathrm{pH}, \mathrm{EC}$, TDS, dissolved ions, and DOC and DOM compositions evaluated by fluorescence EEM analysis. The initial $\mathrm{pH}, \mathrm{EC}$, and TDS values were $6.9 \pm 0.17,19.5 \pm 0.98 \mathrm{mS} / \mathrm{m}$ and $9.17 \pm 0.38 \mathrm{mg} / \mathrm{L}$, respectively $(n=8)$. The $\mathrm{UV}_{260}$ value of rainwater was in the range of $1.31-21.8 \mathrm{~m}^{-1}$ during rainfall events. The mean $\mathrm{UV}_{260}$ was $2.97 \pm 0.31 \mathrm{~m}^{-1}$ in June $(n=5)$, and $7.29 \pm 0.44 \mathrm{~m}^{-1}$ in July $(n=3)$. The significant difference in $\mathrm{UV}_{260}$ suggests that rainwater carried different UV-absorbing DOM from the atmosphere across the sampling periods. The lower absorption in June suggests that the DOM in rainwater was scavenged from the atmosphere below the clouds, as the rainwater amount increased [36]. The DOC concentration was low in June (1.65 mg/L), suggesting that the contribution of organic carbon input is low in terms of DOC in rainwater in Padang.

Six fluorescent components in rainwater were identified by the fluorescence EEM peak-peaking method (Figure 2). The DOM that is identified by fluorescence EEM in rainwater was assigned to protein-like tyrosine (Peak 1: Ex/Em: 230/302 and Peak 4: Ex/Em: 275/302) which derived from autochthonous origin [37,38]. Peak 2 was described as protein-like tryptophan, located at Ex/Em: 240/338, and was also found in rainwater. Peak 3 (Ex/Em: 305/414) was like the terrestrial humic-like fluorophores [39]. Peak 5 (Ex/Em: 320/390) was described as marine humic-like and was often observed in the ocean [37].w Peak 6 (humic-like) was attributed to the UV-absorbing humic fluorescence, which was in Ex/Em: 230/386 and was observed in other rainwater studies [40,41] and considered as microbial humic fluorescence [39]. The intensities of Peaks 1, 2 and 3 were higher than other peaks. There was no significant time variation in DOM composition. The average relative contributions of all peaks to the total value were $32 \%, 27 \%, 21 \%, 10 \%, 5 \%$ and $5 \%$, respectively.

The average concentrations of $\mathrm{NO}_{2^{-}}, \mathrm{NO}_{3^{-}}$and $\mathrm{NH}_{4}{ }^{+}$were $1.61 \pm 0.17,3.87 \pm 0.11$, and $5.74 \pm 0.04 \mathrm{mg} / \mathrm{L}$, respectively $(n=8) . \mathrm{NH}_{4}{ }^{+}$was generally considered to originate from fertilizer, soil, livestock manure and plants. Padang is covered by farmland and the local emissions may influence the changes in ammonium ions in rainwater. $\mathrm{NO}_{2^{-}}$ and $\mathrm{NO}_{3}$ - mainly originate from vehicle emissions and chemical fuel combustion. Motor vehicles lead to an increase and deposition of $\mathrm{NO}_{\mathrm{x}}$ in rainwater [42]. $\mathrm{SO}_{4}{ }^{2+}$ may likely be from a nearby cement industry, which resulted in the presence of $\mathrm{SO}_{4}{ }^{2+}$ in rainwater. $\mathrm{Ca}^{2+}$, $\mathrm{Mg}^{2+}$ and $\mathrm{K}^{+}$in rainwater mainly originate from dust particles and dissolve in rainwater. 


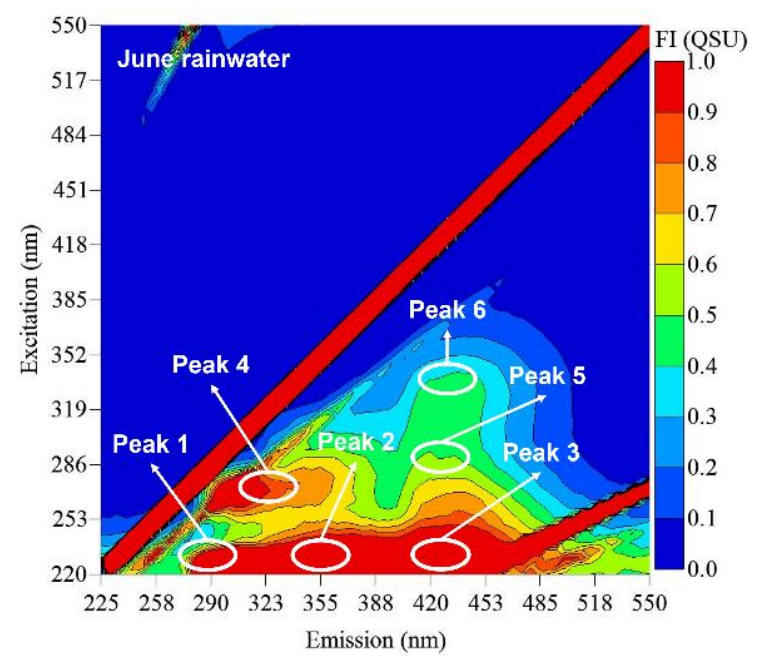

(a)

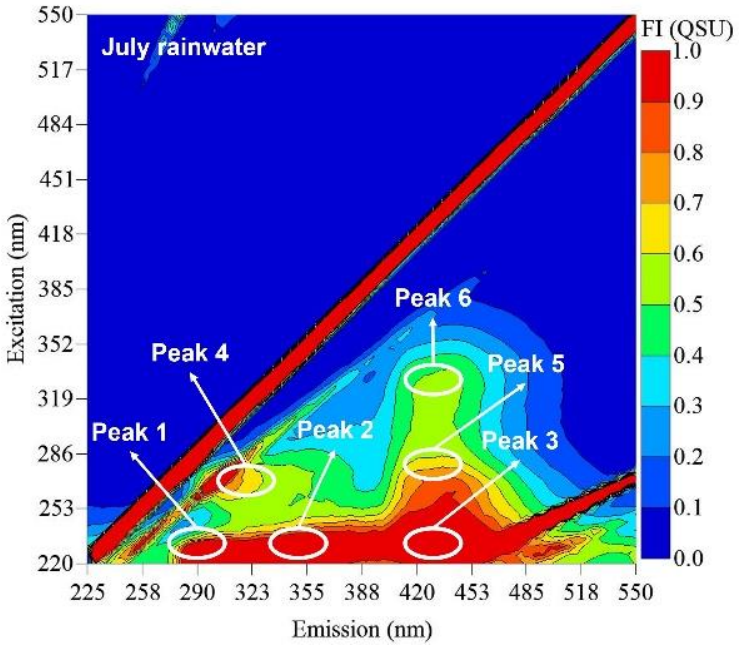

(b)

Figure 2. Fluorescence spectra of rainwater from different sampling periods (a) June (b) July. Peak 1: protein-like tyrosine; Peak 2 and 4: protein-like tryptophan; Peak 3: fulvic acid-like; Peak 5: marine humic-like; and Peak 6: humic-like from fluorescence EEM.

\subsection{Impact of RF on DOC and $U V_{260}$}

Figure 3 shows the reduction in $\mathrm{UV}_{260}$ absorbance and DOC observed during RF treatment. The reduction of $\mathrm{UV}_{260}$ may be attributed to the loss of aromatic and conjugated double bond structures of DOM, due to the oxidation process. $\mathrm{UV}_{260}$ was observed to be reduced by $28 \%$ in $10 \mathrm{~min}$, and $93 \%$ in $60 \mathrm{~min}$, while DOC was reduced by $13 \%$ in $10 \mathrm{~min}$, and $60 \%$ in $60 \mathrm{~min}$. DOC reduction was lower because of the partial oxidation of DOM to other parameters, like $\mathrm{UV}_{260}$. The high reduction of $\mathrm{UV}_{260}$ with a lower reduction of DOC suggests that RF can remove the conjugated double bonds with minimal mineralization [43]. The rapid decrease of $\mathrm{UV}_{260}$ in $30 \mathrm{~min}$ is probably due to the extent of aromatic DOM destruction by the oxidant species generated from the RF reactor. Previous studies reported that organic matter could be highly oxidized in $10 \mathrm{~min}$ through specific reactions [44,45]; thus, rapid degradation of DOM in term of $\mathrm{UV}_{260}$ in this study is explained by the high reactivity of its carbon double bond. A very slight decrease of $U_{\mathrm{V} 260}$ value after 30 min indicates that the remaining UV-absorbing constituents contain moderately activated aromatic rings and were probably attacked by $\bullet \mathrm{OH}$ and $\mathrm{O}_{3}[45]$.

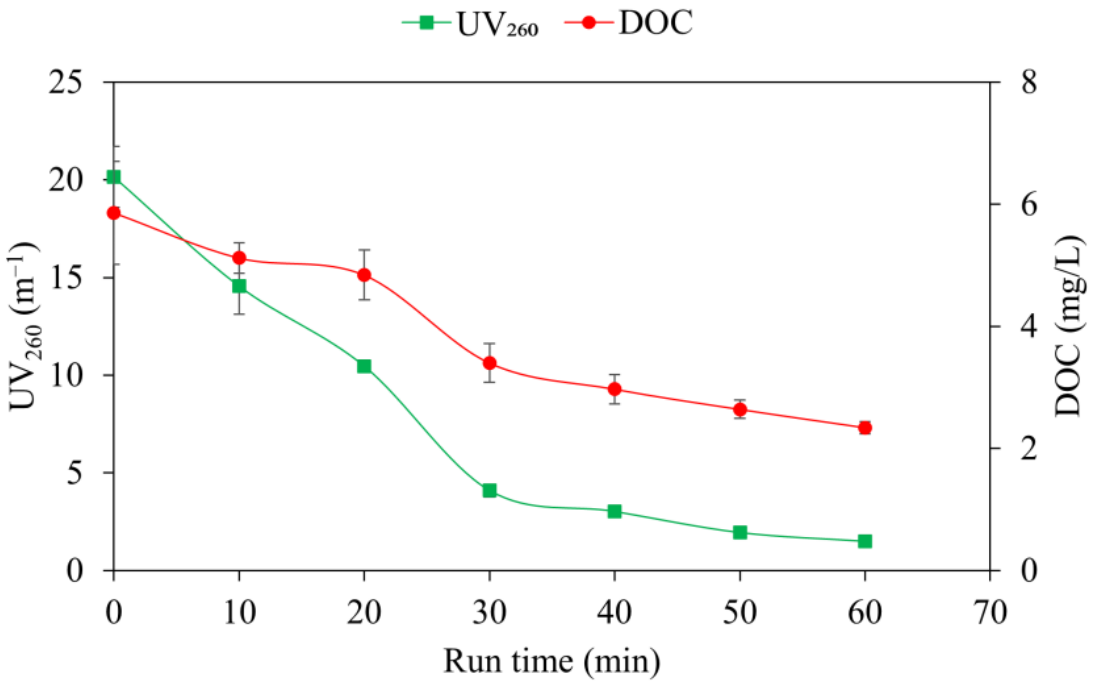

Figure 3. The reduction of $\mathrm{UV}_{260}$ and DOC during RF treatment $(n=8)$. 
During RF treatment, the reduction of DOM was attributed to the chemical oxidation of the DOM present in rainwater by reactive oxidant species, such as $\bullet \mathrm{OH}$ and $\mathrm{O}_{3}$. However, exponential decays of $\mathrm{UV}_{260}$ and DOC were observed, although the chemical degradation kinetics differ between them (data not shown). A previous study revealed that DOC still fell slightly even after five hours with $\mathrm{O}_{3}$ [46]. It is suggested that oxidant species produced in this study were inefficient in reducing DOC. The low change of DOC might also be limited by the ability of electric discharge from RF reactor to transform DOM into lower MW compounds; only a partial transformation of bio-refractory DOM into biodegradable compounds was facilitated. The preliminary results confirm that RF can effectively degrade DOM in less than $1 \mathrm{~h}$ reaction under the adopted experimental conditions. The findings are in agreement with a previous study on the transformation of micropollutants in wastewater using an ozone-based oxidation process [45]. However, since the RF treatment discharges various oxidant species, the specific oxidants that are responsible for the degradation mechanisms of DOM in this study require further investigation.

\subsection{Impact of RF on Fluorescent DOM Composition}

As is shown in Figure 4, the fluorescence intensities of Peak 1, Peak 2 and Peak 3 were much higher than others; thus, they were the main components represented in rainwater and subjected to the degradation process during plasma treatment. Peak 5 and Peak 3 may contain the carboxyl and hydroxyl groups that led to the favorable formation of $\bullet \mathrm{OH}$ and accelerated the degradation rate of organic compounds. The rapid degradation of Peak 5 in $10 \mathrm{~min}$ indicates that the humic-like component was depleted faster than the protein-like component. The protein-like component may have a large molecular weight that results in the incomplete dehydrogenation of aromatic rings [47,48]. A previous study demonstrated oxidation treatment using parallel electrodes during direct electrolysis treatment with the addition of chloride ion [49]. The results show that aromatic macromolecular organic compounds were degraded into small molecular substances, such as acetic acid and phenol. The reasons may be due to the increase of $\mathrm{H}^{+}$that could improve the reaction efficiency between organic matter and reactive species. Simultaneously, it promoted the formation of highly reactive oxygen species, such as $\bullet \mathrm{OH}$, and facilitated the oxidation and decomposition of organic compounds [49]. In this study, RF can generate several reactive species that may assist in the decomposition and degradation of DOM in rainwater during treatment.

Figure 5 shows the changes of fluorescence DOM during RF treatment of rainwater. Peak 1 had the highest intensity at $0 \mathrm{~min}$, indicating that protein-like tyrosine accumulated in rainwater. The intensity of the fluorescent components in the rainwater gradually decreased during plasma treatment. Peaks 1, 2 and 4, which are described as proteinlike compounds, were reduced by $87 \%, 73 \%$ and $87 \%$, while Peaks 3, 5 and 6, which are described as humic-like compounds, were reduced by $67 \%, 97 \%$ and $98 \%$, respectively, from 0 to $60 \mathrm{~min}$. The results indicate that RF consists of high oxidative agents, such as $\bullet \mathrm{OH}$ and $\mathrm{O}_{3}$, which could effectively degrade the humic-like compounds in rainwater. The decrease of DOM composition by plasma was in the following order: Peak $5>$ Peak $3>$ Peak $1 \geq$ Peak $4>$ Peak $2>$ Peak 3 . A fast decrease of Peak 1 and Peak 6 was observed in 10 min of treatment, because of the degradation and mineralization of the DOM with an aromatic structure that reacts quickly with $\bullet \mathrm{OH}[50,51]$. Humic substances are known to be bio-refractory with high stability and aromaticity and can be transformed to become more biodegradable by oxidants generated during RF treatment [41]. 


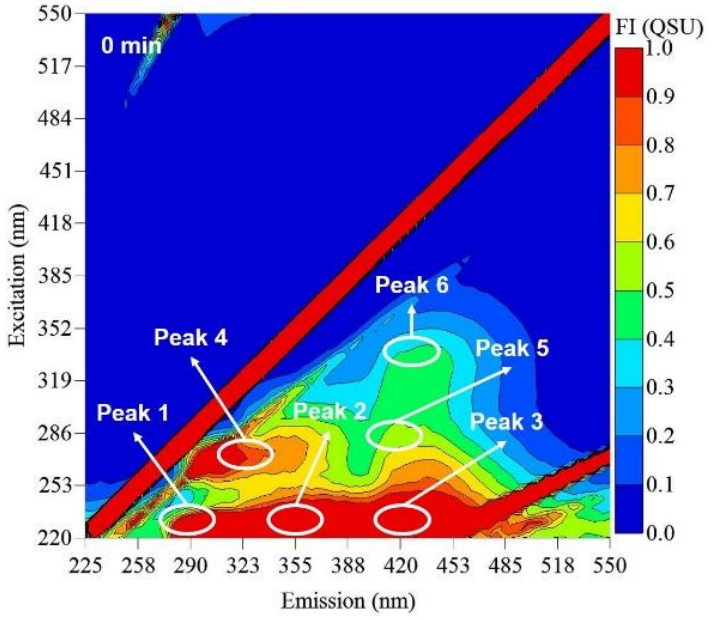

(a)

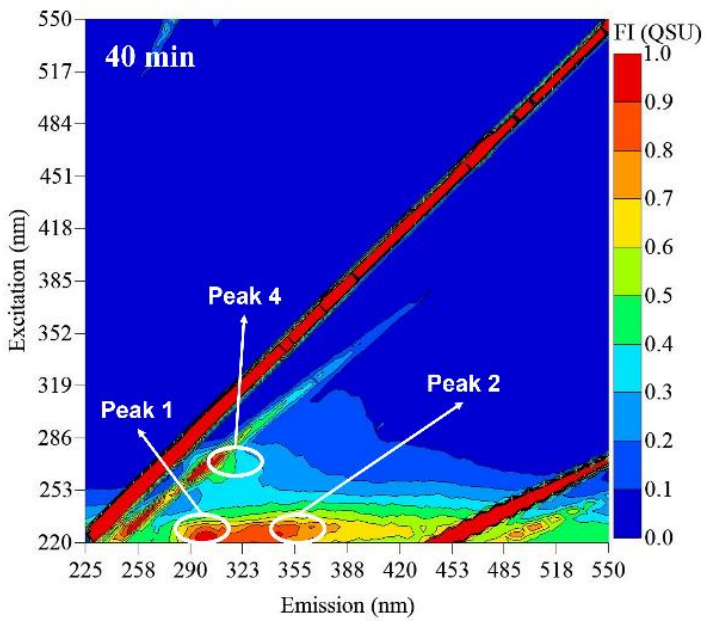

(c)

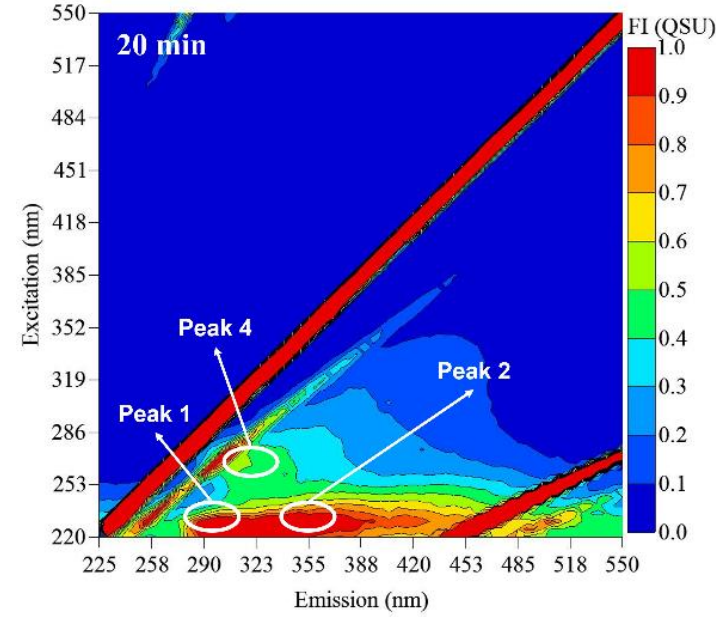

(b)

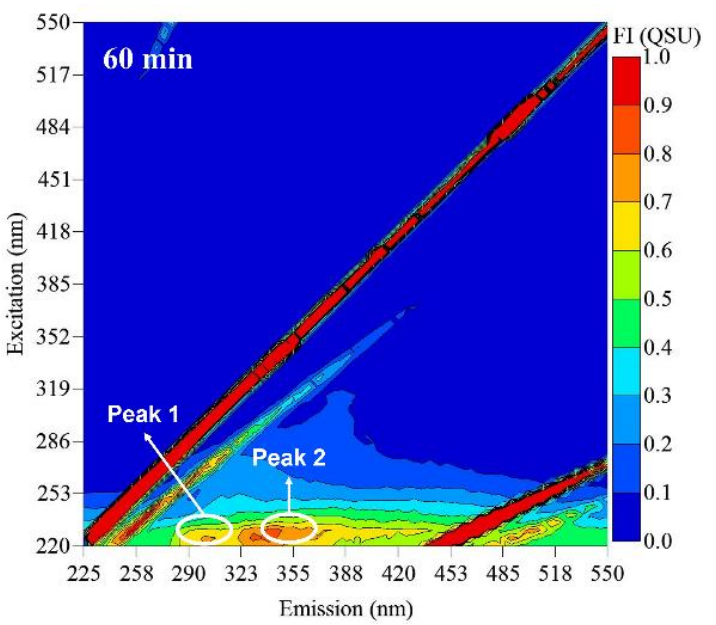

(d)

Figure 4. Fluorescence spectra of rainwater before and after RF treatment. (a) $0 \mathrm{~min}$, (b) $20 \mathrm{~min}$, (c) $40 \mathrm{~min}$, and (d) $60 \mathrm{~min}$. Peak 1: protein-like tyrosine; Peaks 2 and 4: protein-like tryptophan; Peak 3: fulvic acid-like; Peak 5: marine humic-like; and Peak 6: humic-like from fluorescence EEM.

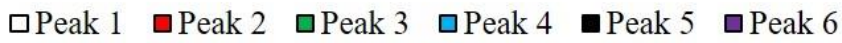

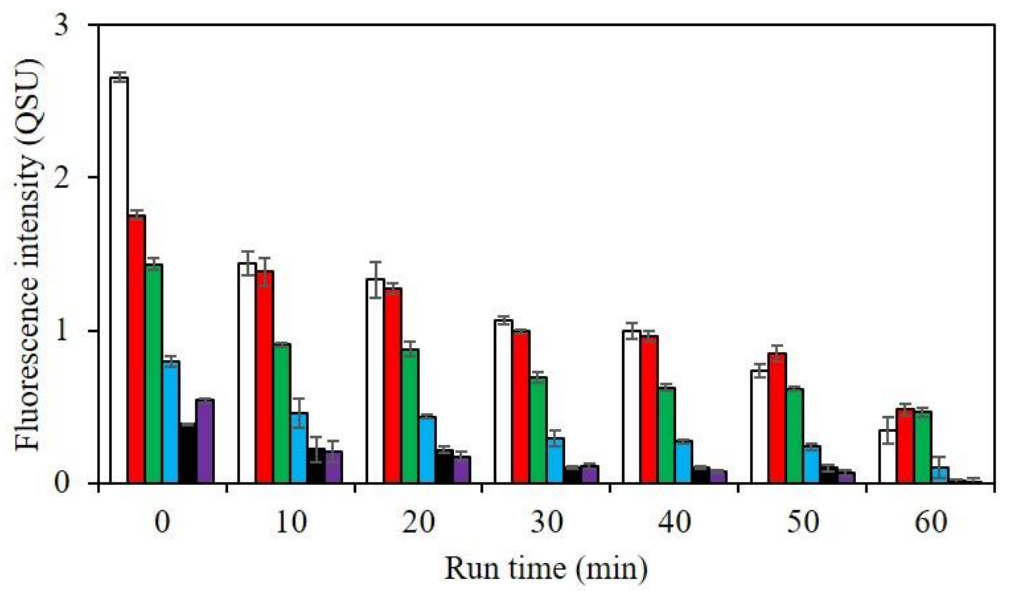

Figure 5. The changes of fluorescence DOM composition during RF treatment $(n=8)$. Peak 1 : protein-like tyrosine; Peaks 2 and 4: protein-like tryptophan; Peak 3: fulvic acid-like; Peak 5: marine humic-like; Peak 6: humic-like. 


\subsection{Impact of RF on $M W$ of DOM}

Figure 6 shows the MW distribution of the DOM in rainwater measured by HPSEC and is given in terms of detector response of UV absorbance at $260 \mathrm{~nm}$. The distributions of MW fractions extracted from HPSEC in rainwater were 32\%, 27\%, 18\%, 12\% and 11\% for HS, LMWN, BP, LWMA and BB, respectively. HS are not easily biodegradable. However, oxidation by RF can remove $78 \%$ of HS that can be attributed to the molecule breakdown into a low MW size. Rainwater featured a large MW, and the total response decreased after RF treatment was applied. The result suggests that RF facilitated the oxidation of aromatic or double bond organic matter into lower MW compounds. This study showed that the apparent high MW that consisted of BP and HS may contain high aromaticity humic molecules that are easy to degrade through oxidation process. The oxidants generated by the RF reactor assisted the unsaturated functional groups to break down into smaller molecules which are more biodegradable [52].

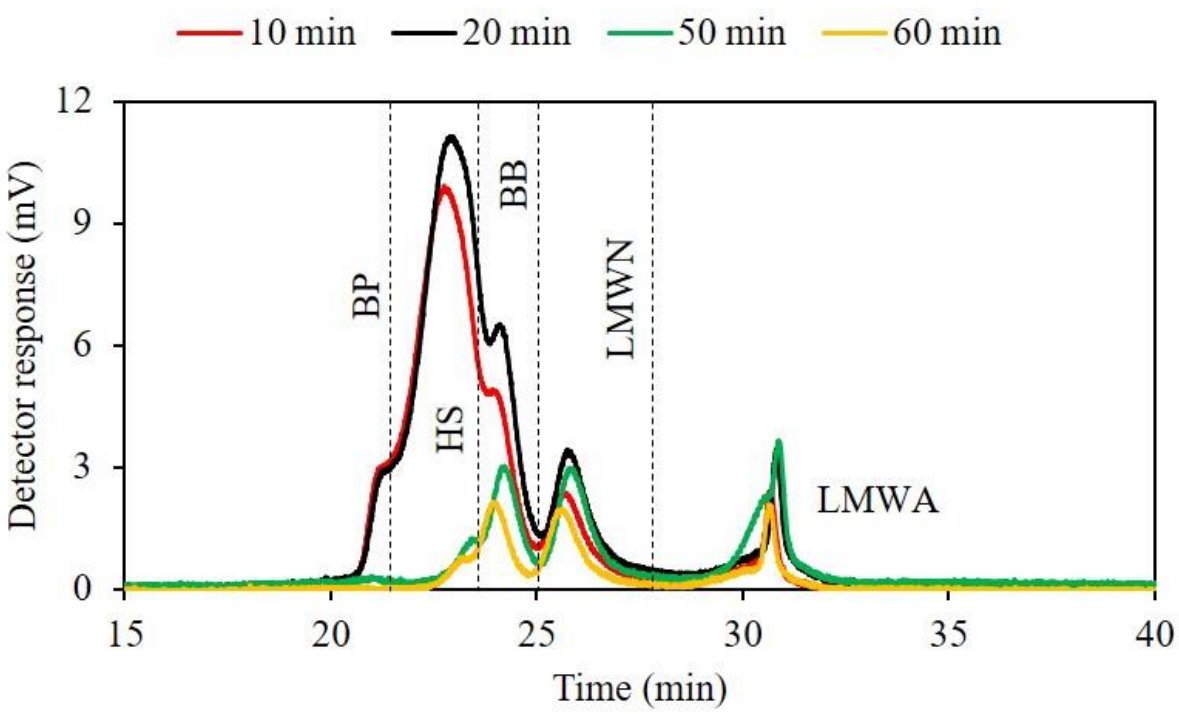

Figure 6. MW distribution in rainwater sampled on 27 July 2019. BP: biopolymer; HS: humic substances; BB: building blocks; LMWN: low MW neutral; LMWA: low MW acid.

RF was found to reduce the $>8 \mathrm{kDa}$ and 5-7 kDa MW fractions of organic matter by $83 \%$ and $79.6 \%$, respectively, in a 60 min treatment (Figure 7 ). RF demonstrated that larger MW DOM was reduced more than that of lower MW DOM, indicating that the higher reaction rate is constant among oxidant species, such as $\bullet \mathrm{OH}$ and $\mathrm{O}_{3}$ produced from RF plasma and the larger MW compounds [53]. Higher MW compounds tend to be more aromatic, so they may have a larger number of reaction sites compared to smaller MW compounds [43]. The decreasing trend of MW size of DOM during RF treatment is consistent with the decreasing trend of $\mathrm{UV}_{260}$ value, where aromatics transformation leads to the formation of low MW products. RF treatment removed DOM with molecular size $<3 \mathrm{kDa}$ less than DOM with molecular size $>5 \mathrm{kDa}$. This result confirms that RF treatment facilitates the faster degradation for high MW. This study is concordant with previous studies on the effects of advanced oxidation processes on DOM removal [52,53]. 


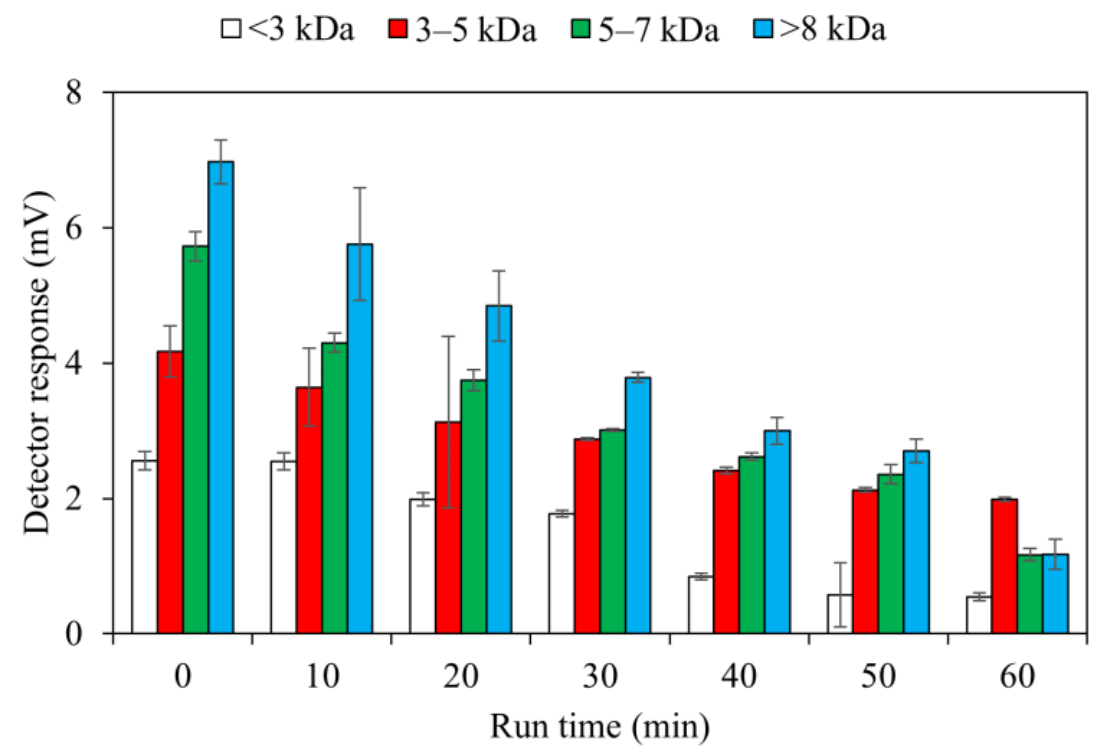

Figure 7. The changes of molecular size of DOM during RF treatment $(n=8)$.

\section{Conclusions}

This study investigated the impact of RF treatment on the levels of DOM in rainwater. DOM in rainwater was reduced during RF treatment through oxidation by reactive oxidant species produced by the RF. This study demonstrated that RF could remove $96 \%$ of $U_{2} 260$ substances that may comprise humic molecules by oxidation through high mineralization. DOM compositions assessed by fluorescence EEM showed that humic-like compounds are more easily degraded than protein-like compounds. Humic-like compounds were reduced by $97 \%$, indicating that oxidant species produced by RF could transform non-biodegradable aromatic humic molecules to become biodegradable. Oxidant species produced by RF can also transform high MW fractions into low ones. $\bullet \mathrm{OH}$ and $\mathrm{O}_{3}$ can easily attack and oxidise the reaction site in an aromatic structure. However, the dominant oxidant species produced from RF in this study remain unclear. Further work is needed to identify specific reactive oxidant species that correspond to the reduction of DOM in rainwater. The current operational study of RF also shows the need for further exploration on the DOM reduction. This work offers valuable information on understanding potential RF treatment for water source and drinking water conservation and treatment.

Author Contributions: Conceptualization, R.D. and M.Y.R.; methodology, R.D. and A.H.; validation, R.D., A.H. and F.L. investigation, R.D.; writing—original draft preparation, M.Y.R. and R.D.; writing-review and editing, M.Y.R., R.D., A.H. and F.L.; supervision, A.H. and F.L. All authors have read and agreed to the published version of the manuscript.

Funding: This research was funded by the Ministry of Education, Culture, Research and Technology of Indonesia with grant number 023-36/LPPM-Penelitian/Hatta/I-2021.

Institutional Review Board Statement: Not applicable.

Informed Consent Statement: Not applicable.

Acknowledgments: We would like to thank the Ministry of Education, Culture, Research and Technology Indonesia for supporting this work with Grand Number 170/E4.1/AK.04.PT/2021. We would like to express our gratitude and thank the Water and Wastewater Laboratory team, Department of Chemical Engineering for the investigation and field survey. We also would like to thank the students of the Department of Chemical Engineering, Universitas Bung Hatta and Department of Electrical Engineering, Andalas University for designing the RF treatment systems.

Conflicts of Interest: The authors report no conflict of interest. 


\section{References}

1. Campasino, A.; Butler, D.; Ward, S.; Burns, M.J.; Friedler, E.; DeBusk, K.; Fisher-Jeffes, L.N.; Gishi, E.; Rahman, A.; Furumai, H.; et al. Urban rainwater harvesting systems: Research, implementation and future perspectives. Water Res. 2017, 115, 195-209. [CrossRef] [PubMed]

2. Zhang, S.; Zhang, J.; Yue, T.; Jing, X. Impacts of climate change on urban rainwater harvesting system. Sci. Total Environ. 2019, 665, 262-274. [CrossRef]

3. Musayev, S.; Burgess, B.; Mellor, J. A global performance assessment of rainwater harvesting under climate change. Resour. Conserv. Recycl. 2018, 132, 62-70. [CrossRef]

4. Chapa, F.; Krauss, M.; Hack, J. A multi-parameter method to quantify the potential of roof rainwater harvesting at regional levels in areas with limited rainfall data. Resour. Conserv. Recycl. 2010, 161, 104959. [CrossRef]

5. Bui, T.T.; Nguyen, D.C.; Han, Y.; Kim, M.; Park, H. Rainwater as a source of drinking water: A resource recovery case study from Vietnam. J. Water Process Eng. 2011, 39, 101740. [CrossRef]

6. Sharma, A.K.; Cook, S.; Gardner, T.; Tjandraatmadja, G. Rainwater tanks in modern cities: A review of current practices and research. J. Water Clim. Chang. 2016, 7, 445-466. [CrossRef]

7. Nodle, E. Possibilities of rainwater utilisation in densely populated area including precipitation runoffs from traffic surfaces. Desalination 2017, 215, 1-11. [CrossRef]

8. Villarreal, E.L.; Dixon, A. Analysis for a rainwater collection system for domestic water supply in Ringdansen, Norrkoping, Sweden. Build. Environ. 2015, 40, 1174-1184. [CrossRef]

9. Kim, Y.K.; Han, M.Y.; Kabubi, J.; Sohn, H.G.; Nguyen, D.C. Community-based rainwater harvesting (CB-RWH) to supply drinking water in developing countries: Lessons learned from case studies in Africa and Asia. Water Supply 2016, 16, 1110-1121. [CrossRef]

10. Daniel, D.; Djohan, D.; Machairas, I.; Pande, S.; Arifin, A.; Al Djono, T.P.; Rietveld, L. Financial, institutional, environmental, technical, and social (FIETS) aspects of water, sanitation, and hygiene conditions in indigenous-Rural Indonesia. BMC Public Health 2021, 21, 1723. [CrossRef] [PubMed]

11. Battin, T.J.; Luyssaert, S.; Kaplan, L.A.; Aufdenkampe, A.K.; Richter, A.; Tranvik, L.J. The boundless carbon cycle. Nat. Geosci. 2009, 2, 598-600. [CrossRef]

12. Li, S.; Fan, R.; Luo, D.; Xue, Q.; Li, L.; Yu, X.; Huang, T.; Yang, H.; Huang, C. Variation in quantity and quality of rainwater dissolved organic matter (DOM) in a peri-urban region: Implications for the effect of seasonal patterns on DOM fates. Atmos. Environ. 2020, 239, 117769. [CrossRef]

13. Soares, M.A.; Sabu, P.; Anilkumar, N.; Mishra, R.K.; Naik, R.K.; Bhaskar, P.V.; George, J.V.; Venkataramana, V.; Sarkar, A. variation of particulate organic matter characteristics in the upper water column of eddy-influenced waters at the subtropical front of the Indian sector of the Southern Ocean. J. Sea Res. 2021, 174, 102074. [CrossRef]

14. Orlović-Leko, P.; Vidović, K.; Ciglenečki, I.; Omanović, D.; Sikirić, M.D.; Šimunić, I. Physico-chemical characterization of an urban rainwater (Zagreb, Croatia). Atmosphere 2020, 11, 144. [CrossRef]

15. Gao, B.; Yu, J.Z.; Li, S.X.; Ding, X.; He, Q.F.; Wang, X.M. Roadside and rooftop measurements of polycyclic aromatic hydrocarbons in PM 2.5 in urban Guangzhou: Evaluation of vehicular and regional combustion source contribution. Atmos. Environ. 2011, 45, 7184-7191. [CrossRef]

16. Zhang, Y.; Lang, J.; Cheng, S.; Li, S.; Zhou, Y.; Chen, D.; Zhang, H.; Wang, H. Chemical composition and sources of PM 1 and 2.5 in Beijing in autumn. Sci. Total Environ. 2018, 630, 72-82. [CrossRef] [PubMed]

17. Zheng, G.; He, K.; Duan, F.; Cheng, Y.; Ma, Y. Measurement of humic-like substances in aerosols: A review. Environ. Pollut. 2013, 188, 301-314. [CrossRef]

18. Huo, M.Q.; Sato, K.; Ohizumi, T.; Akimoto, H.; Takahashi, K. Characteristics of carbonaceous components in precipitation and atmospheric particle at Japanese sites. Atmos. Environ. 2016, 146, 164-173. [CrossRef]

19. Rafiq, M.; Mishra, A.K.; Meer, M.S. On land-use and land-cover changes over Lidder Valley in changing environment. Ann. GIS 2018, 24, 275-285. [CrossRef]

20. Environmental Protection and Management, Law of the Republic of Indonesia 32. 2009. Available online: https://jdih.esdm.go.id (accessed on 30 December 2021).

21. Chen, X.; Wang, Y.; Li, W.Y.; Zhang, J.P.; Qi, W.Q.; Lu, Y.F.; Ding, Z.B. Coupling changes of disinfectant and bacteria induced stagnation and disinfection strategy. Chemosphere 2020, 242, 125190. [CrossRef]

22. Vilhunen, S.; Silanpää, M. Recent developments in photochemical and chemical AOPs in water treatment: A mini-review. Rev. Environ. Sci. Bio/Technol. 2010, 9, 323-330. [CrossRef]

23. Li, H.; Zhao, Z.; Xiouras, C.; Stefanidis, D.; Li, X.; Gao, X. Fundamentals and applications of microwave heating to chemical separation processes. Renew. Sustain. Energy Rev. 2019, 114, 109316. [CrossRef]

24. Kovaleva, L.; Zinnatullin, R.; Gabdrafikov, A.; Sultanguzhin, R.; Kireev, V. Influence of radio-frequency and microwave electromagnetic treatment on water-in-oil emulsion separation. Colloids Surf. A Physicochem. Eng. Asp. 2021, 614, 126081. [CrossRef]

25. Desmiarti, R.; Hazmi, A.; Trianda, Y.; Sari, E. Removal of pathogenic bacteria from water by radio-frequency thermal plasma treatment. Res. J. Pharm. Biol. Chem. Sci. 2015, 6, 889-897.

26. Jiang, B.; Zheng, J.; Liu, Q.; Wu, M. Degradation of organic dye by pulsed discharge non-thermal plasma technology assisted with modified activated carbon fibers. Chem. Eng. J. 2013, 215-216, 969-978. [CrossRef] 
27. De la Hoz, A.; Díaz-Ortiz, A.; Moreno, A. Review on non-thermal effects of microwave irradiation in organic synthesis. J. Microw. Power Electromagn. Energy 2007, 41, 45-66. [CrossRef]

28. Subedi, D.P.; Tyata, R.B.; Khadgi, A.; Wong, S.C. Treatment of water by dielectric barrier discharge. J. Sci. Technol. Trop. 2009, 5, 117-123.

29. Sun, B.; Sato, M.; Clements, J.D. Optical study of active species produced by a pulsed streamer corona discharge in water. J. Electrost. 1997, 39, 189-202. [CrossRef]

30. Desmiarti, R.; Sari, E.; Vallepi, R.R.; Wahyeni, F.S.; Rosadi, M.Y.; Hazmi, A. Drinking water production from rainwater using radio frequency plasma system. In IOP Conference Series: Materials Science and Engineering; IOP Publishing: Bristol, UK, 2020; Volume 990, p. 012019. [CrossRef]

31. Desmiarti, R.; Hazmi, A.; Trianda, Y.; Ramayandi, R.; Yamada, T.; Li, F. Enhancement of drinking water treatment by combined filtration-ICPS: Integrated, based on EEMS, DOC, UV260 and removal pathogenic bacteria. Int. J. Technol. 2019, 10, 593-602. [CrossRef]

32. Vorontsov, A.V. Advancing Fenton and photo-Fenton water treatment through the catalyst design. J. Hazard. Mater. 2019, 372, 103-112. [CrossRef] [PubMed]

33. Ya, V.; Chen, Y.C.; Chou, Y.H.; Choo, K.H.; Liu, J.C.; Mameda, N.; Li, C.W. Cryolite (Na $\left.\mathrm{NlF}_{6}\right)$ crystallization for fluoride recovery using electrolytic process equipped with a sacrificial aluminum anode. J. Hazard. Mater. 2019, 326, 90-96. [CrossRef]

34. Yacouba, Z.A.; Mendret, J.; Lesage, G.; Zaviska, F.; Brosillon, S. Removal of organic micropollutants from domestic wastewater: The effect of ozone-based advanced oxidation process on nanofiltration. J. Water Process Eng. 2021, 39, 101869. [CrossRef]

35. PSDA Provinsi Sumatra Barat, Rainfall Statistics. 2019. Available online: http://psda.sumbarprov.go.id/details/hujan (accessed on 15 October 2019).

36. Zhang, Y.; Gao, G.; Shi, K.; Niu, C.; Zhou, Y.; Qin, B.; Liu, X. Absorption and fluorescence characteristics of rainwater CDOM and contribution to Lake Taihu, China. Atmos. Environ. 2014, 98, 483-491. [CrossRef]

37. Coble, P.G.; Del Castillo, C.E.; Avril, B. Distribution of CDOM in the Arabian Sea during the 1995 Southwest Monsoon. Deep-Sea Res. Part II 1998, 45, 2195-2223. [CrossRef]

38. Kowalczuk, P.; Durako, M.J.; Young, H.; Kahn, A.E.; Cooper, W.J.; Gonsior, M. Characterization of dissolved organic matter fluorescence in the South Atlantic Bight with use of PARAFAC model: Interannual variability. Mar. Chem. 2009, 113, 182-196. [CrossRef]

39. Fellman, J.B.; Hood, E.; Spencer, R.G.M. Fluorescence spectroscopy opens new windows into dissolved organic matter dynamics in freshwater ecosystems: A review. Limnol. Oceanogr. 2010, 55, 2452-2462. [CrossRef]

40. Salve, P.R.; Lohkare, H.; Gobre, T.; Bodhe, G.; Krupadam, R.J.; Ramteke, D.S.; Wate, S.R. Characterization of chromophoric dissolved organic matter (CDOM) in rainwater using fluorescence spectrophotometry. Bull. Environ. Contam. Toxicol. 2012, 88, 215-218. [CrossRef] [PubMed]

41. Santos, P.S.; Duarte, R.M.; Duarte, A.C. Absorption and fluorescence properties of rainwater during the cold season at a town in Western Portugal. J. Atmos. Chem. 2009, 62, 45-57. [CrossRef]

42. Liu, J.F.; Song, Z.G.; Xu, T. Study on ionic composition of rainwater at Guangzhou and the primary factors of rainwater acidity. Huan Jing Ke Xue = Huanjing Kexue 2002, 27, 1998-2002.

43. Lamsal, R.; Walsh, M.E.; Gagnon, G.A. Comparison of advanced oxidation process for the removal of natural organic matter Water Res. 2011, 45, 3263-3269. [CrossRef]

44. Lee, M.; Zimmermann-Steffens, S.G.; Arey, J.S.; Fenner, K.; von Gunten, U. Development of prediction models for the reactivity of organic compounds with ozone in aqueous solution by quantum chemical calculations: The role of delocalized and localized molecular orbitals. Environ. Sci. Technol. 2015, 49, 9925-9935. [CrossRef]

45. Azaïs, A.; Mendret, J.; Cazals, G.; Petit, E.; Brosillon, S. Ozonation as a pretreatment process for nanofiltration brines: Monitoring of transformation products and toxicity evaluation. J. Hazard. Mater. 2017, 338, 381-393. [CrossRef] [PubMed]

46. Byun, S.; Taurozzi, J.S.; Tarabara, V.V. Ozonation as pretreatment for nanofiltration: Effect of oxidation pathway on the permeate flux. Sep. Purif. Technol. 2015, 149, 174-182. [CrossRef]

47. Ike, I.A.; Lee, Y.; Hur, J. Impacts of advanced oxidation processes on disinfection by-products from dissolved organic matter upon post-chlor(am)ination: A critical review. Chem. Eng. J. 2019, 375, 121929. [CrossRef]

48. Zhang, S.; Rouge, V.; Gutierrez, L.; Croue, J.P. Reactivity of chromophoric dissolved organic matter (CDOM) to sulfate radicals: Reaction kinetics and structural transformation. Water Res. 2019, 163, 114846. [CrossRef]

49. Wang, H.; Quan, B.; Bo, G.; Zhang, Y.; Liu, L.; Zhang, J.; Zhang, X.; Zhang, C. Advanced oxidation treatment of dissolved organic matter from wastewater treatment plant secondary effluent using scattering electrical reactor. J. Clean. Prod. 2020, 267, 122258. [CrossRef]

50. Maghsoodi, M.; Jacquin, C.; Teychené, B.; Heran, M.; Tarabara, V.V.; Lesage, G.; Snow, S.D. Emerging investigator series: Photocatalysis for MBR effluent post-treatment: Assessing the effects of effluent organic matter characteristics. Environ. Sci. Water Res. Technol. 2019, 5, 482-484. [CrossRef]

51. Sid, S.; Volant, A.; Lesage, G.; Heran, M. Cost minimization in a full-scale conventional wastewater treatment plant: Associated costs of biological energy consumption versus sludge production. Water Sci. Technol. 2017, 76, 2473-2481. [CrossRef]

52. Liu, C.; Li, P.; Tang, X.; Korshin, G.V. Ozonation effects on emerging micropollutants and effluent organic matter in wastewater: Characterization using changes of three-dimensional HP-SEC and EEM fluorescence data. Environ. Sci. Pollut. Res. 2016, 23, 20567-20579. [CrossRef]

53. Rozario-Ortiz, F.L.; Wert, E.C.; Snyder, S.A. Evaluation of UV $/ \mathrm{H}_{2} \mathrm{O}_{2}$ treatment for the oxidation of pharmaceuticals in wastewater. Water Res. 2010, 44, 1440-1448. [CrossRef] [PubMed] 